\title{
中学・高等学校の理科系部活動における探究活動のテーマ分析 一東京都内の研究発表会の事例から一
}

\author{
松岡 雅忠 ${ }^{1}$
}

\begin{abstract}
【要
約】

中学・高等学校の理科系部活動では, テーマを設定した継続的な探究活動などが実践され ており，科学好きな生徒を育てる場として重要である。本研究の目的の一つは，放課後や長 期休業日に行われる探究活動の実態についての調査を行うことである。まず，東京都の私立 中学・高等学校の生徒が参加する「生徒理科研究発表会」を対象に, 1961 年度から 2015 年 度までの 55 年間に発表された, 中学 759 件, 高校 1,349 件の研究報告を整理し分析した。そ の結果, 近年, 物理や化学を中心に応募件数が増加していることや, 研究報告に含まれる動 植物のスケッチや実験装置の見取り図の割合が減少し，写真の割合が急増していることを見 出した。もう一つの目的は, 学校ごとの設備の違いや学校周辺の自然環境によってテーマの 影響を受けにくいと考えられる，化学分野を中心に研究テーマの調査を行うことにある。化 学分野を 12 の領域に分け, 作品ごとの概要やどのような点で人気があるかを, 学校種や時代 背景を踏まえつつ分析した。化学分野では, 自然環境に関する調查が伝統的に行われている ほか, 金属の変化, 染色, 色变化を伴う化学反応など, 視覚的な変化に注目する研究テーマ を選択する傾向がみられた。
\end{abstract}

[キーワード] 自由研究, 実験, 化学, 部活動

\section{1.はじめに}

理科の自由研究 ${ }^{1)}$ は, 理科教育の中で長く取り 組まれており, 夏休みの宿題として多くの小・中学 生が体験している。(独) 科学技術振興機構( 2009 , 2013）の調査では， 77\%の览童・生徒が「(小学校・ 中学校で）理科の自由研究をしたことがある」と回 答している。児童・生徒は, 日常生活で関心を持っ たことに対して課題を設定し，レポートや作品を製 作・提出する。

自由研究の実施状況や事前・事後指導の方法につ いては, 伝統的に理科の自由研究が盛んな地域の中 学校での事例が報告されている。

たとえば, 新城ら（1977）は那覇市内の中学校を 例に,「授業の各段階で, 指導内容と関連のある自由 研究の, 実験・観察・観測等の過程や結果を生徒自 身に発表させ, 教師が補足説明を行う」指導方法の 有用性を指摘している。また, 杉尾（2009）は那覇

\footnotetext{
${ }^{1}$ 駒場東邦中学・高等学校
}

市内の中学校の理科教員を対象にした意識調査を行 い, 自由研究の大切さ（問題解決能力の育成, 家庭 での話題になるなど）を多くの教員が認めている一 方で，時間的な制約等から必ずしも十分な指導が行 えない現状があること，博物館など外部機関との連 携，学校と家庭が協力した取り組みを期待する声が 上がったことを報告している。

同様に, 安藤（2007a）は川崎市理科作品展に出展 された作品の分類を行い, 自由研究を単に夏休みの 宿題として終わらせるのではなく，1学期の段階か ら指導・援助を行い，「科学コンテストを自由研究の 延長として利用する学習モデル」を提案している。

さらに, 研究テーマの変遷や, 児童・生徒, 教員 等の認識に関する調査も広く行われている。たとえ ば，日比野ら（2014）は，岐阜市の小中学校を例に, 研究テーマが教科書の「自由研究の取り組み」でと りあげられた題材に影響を受けやすいこと，近年で は，自由研究を扱った書籍や実験キットの普及によ りテーマが多様化していることを見出している。

安藤（2007b）は, 全ての中学校で自由研究が行わ 
れている川崎市の公立中学校教員対象のアンケート 結果から, 自由研究によって生徒に身につくと考え られる態度（自然事象への興味や関心，知的好奇心 など）について教員がおおむね肯定的であると分析 している。一方, 海野・安藤（2009）は, 他県の中 学校生徒を対象にアンケート調査を行ったところ, 自由研究に費やした時間が 4 時間未満の生徒が全体 の約半数に及ぶこと, および, 自由研究に対する肯 定的な意識がみられたが, 「楽しさ」,「役立ち度」が 有意に低く, 指導のいかんによっては, 自由研究が 半ば義務的な活動と捉えられる恐れがあることを指 摘している。

これらの調査結果を踏まえ, 大山（2015）は, 中 学 1 年次の 1 学期の授業で自由研究の事前指導 (与 えられた課題の中から班で 1 つを選び 2 時間の「測 定を伴う」実験を行わせる）を行うことで, 夏休み の後に提出される自由研究レポートで定量的な考察 をする生徒が大幅に増加し, 理科の学習意欲の向上 につながったことを報告している。

また，高等学校における課題研究の実践例として はスーパーサイエンスハイスクール ( $\mathrm{SSH}$ ) 事業の 一環としての活動が知られている。SSH 事業におけ る課題研究は, 「科学に関する課題を設定し, 観察・ 実験等を通した研究において, 大学・企業等の支援 を受けながら, 主体的・協働的に実施」する（文部 科学省, 2016）点が特徴的である。

このほか, 理数·工業・農業・水産の専門学科で も「課題研究」の科目が設定されており,「自ら設定 した（専門学科に関する）課題について, その解決 を目指して学習させる」(文部科学省, 2009) ことを 目標に, 学校や地域の特色を生かした研究が実施さ れている。

これらの場合を除き, 高等学校では授業以外の自 由研究や探究活動を行う機会は限られているのが実 情であろう。(独) 国立青少年教育振興機構による調 査（2014）では，「学校の授業以外に自分で観察や実 験を行い, 結果をレポートや論文などにまとめたこ とがある」高校生の割合は $5 \%$ を下回っている。

ところで, 中学校や高等学校の理科系部活動（こ こでは, 放課後や長期休業日に行われる, 授業の一 環ではない課外活動を指す）は多くの学校に存在 し, 文化祭や地域のイベントなどでの実験デモンス トレーションだけでなく, テーマを設定した継続的 な探究活動などが実践されており, 科学好きな生徒 を育てる場として, また, 数年という長いスパンで の課題研究を体験できる場としても重要である。部 活動の成果を，全国的な論文コンクールである日
本学生科学賞 (読売新聞社主催) やジャパン・サ イエンス・アンド・エンジニアリング・チャレン ジ（JSEC，朝日新聞社主催）に応募し, 全国審査で 入選・入賞する作品も多い。木村 (2014) は, 愛知 県刈谷市の中学校理科研究発表会を例に, 研究テー マを設定する際に生徒にアドバイスを与えることが 目的意識の向上につながることや，指導者間の研修 によりノウハウを共有することの重要性を指摘して いる。

そのため, 中学・高等学校の理科系部活動の指導 者にとって, 生徒達がどのような研究テーマを選ん で探究活動を行っているかの情報は有益であると考 えられる。

SSH や専門学科に扔ける課題研究は, その研究 テーマによっては, 特殊な実験装置が必要となるた め, 中学・高等学校で実施することが困難であるも のを含む。また，全国的な論文コンクールの入選作 品は完成されたものであり, 探究活動のスタートラ インに立つ生徒の目標とはなるが, 自分たちの研究 テーマとして選択するにはハードルが高い。

そこで筆者は, SSH や専門学科での課題研究の成 果の発表の場とはなってこなかった，東京都の私立 中学・高等学校の理科系部活動に所属する生徒が主 に参加する「生徒理科研究発表会」に注目した。

\section{2. 研究の目的}

本稿では, 55 年間の「生徒理科研究発表会」の内 容の中の, 特に化学分野の研究テーマについて分析 し, 中学・高等学校における理科 (化学) 系部活動 の指導の基礎資料を作成する。

\section{3. 調査方法}

\section{1 研究発表会の概要}

東京私立中学高等学校協会文化部が主催する「生 徒理科研究発表会」は, 昭和 36 年度 (1961 年度) にスタートして以来, 平成 27 年度（2015 年度）で 第 55 回を迎える。

本発表会の発起人である多田元一（当時・東海大 学高輪台高等学校長) は, 第 15 回記念誌 (1976) に 以下のように回想している。

「昭和 32 年 1 月 1 日の読売新聞の第 1 面に新しい 事業として『日本学生科学賞』の創設が公にされ た。中・高校の生徒が行った地道な理科に関する 研究が, 堰を切ったように全国から寄せられた。 誠に偉観であった。(中略) 都内には私立の中・高 校は数多い。これらの学校で理科に関する研究も 多々あるが, 生徒の研究に関する発表の機会は皆 
無に近い。これをそのままにするのではなく公開 の機会を作るべきである。（中略）協会内に次第に 雾囲気を醸成し, そして待望の幕は切って落とさ れた。」

本発表会は中学校の部, 高等学校の部からなり, それぞれ物理・化学・生物・地学のうちから分野を 選択して研究発表を行う。なお, 理科系部活動では, 工作，情報（ロボット，コンピュータの活用など） や数理科学などの多様な研究テーマが存在するが, 発表会への応募に際しては, 上記 4 分野から選択す ることとなっている。

口頭発表は各校とも中学・高等学校それぞれ 1 件 に限られるが, 誌上発表の件数に制限はなく, 都内 の私立中学・高等学校の理科系部活動の生徒にとっ ての目標となっている。なお, 審査はなく, 発表者 全員に賞状が与えられる。

この発表会は毎年 2 月に行われているため, 一学 期からスタートさせた探究活動の成果を発表する夕 イミングとして適している（複数年にわたる研究も 存在する）ほか，公立の中学校では高校受験期に当 たる中学 3 年生も発表することができる。長期間に わたる探究活動の成果を, 発表件数の制限なく報告 できることは，分析する上でのメリットでもある。

図 1 は，発表会の参加校の推移を表したグラフで ある。中高一貫校および，中学校を併設している高 等学校では，中・高を別とせず 1 校としている。こ れは，中高一貫校などでは，一つの部活動の中で高 校生が中学生と活動を行う場合が多いためである。

発表会参加校は近年増加傾向にあるが, ここ 30 年

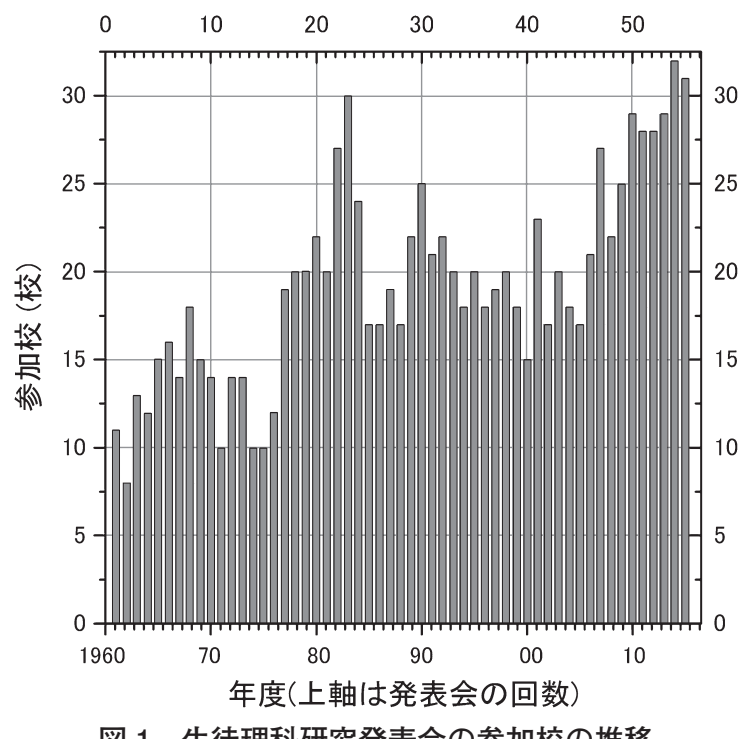

間は常連ともいえる 20〜30 校で推移している。ちな みに, 2016 年 4 月現在, 都内の私立中学校は 188 校, 高等学校は 237 校存在する。

\section{2 調査内容}

まず，過去 55 回の研究紀要に掲載された，中学 759 件, 高校 1,349 件の研究報告を物理・化学・生 物・地学の 4 分野に分類した。

続いて, 研究報告中の図版等の調査を行い, 生徒 がどのように実験デー夕を処理しているか，また， コンピュータやデジタルカメラの普及により研究報 告の形式にどのような変化が生じたかを調査した。

さらに，化学分野を中心に研究テーマを分類し， その概要を紹介するとともに，学校種や時代背景を 踏まえつつ分析した。

\section{4. 調査結果と考察}

\section{1 研究発表会の発表件数}

生徒理科研究発表会における年度ごとの発表件数 の推移を図 2 (中学校), 図 3 (高等学校) にまとめた。 第 15 回（1976 年度）までは各学校 1 件の口頭発表 のみであったため，発表件数は限られていたが，そ れ以降は誌上発表が導入され，第 40 回（2001 年度） までは中学・高等学校あわせて 40 件程度で推移して いる。とりわけ，第 45 回（2006 年度）以降の 10 年 間は，参加校の数も増加傾向にあるが，発表件数が 大幅に増加している。生徒理科研究発表会運営委員 会によると，その背景として，ホームページが（期 間限定で）開設されたため，認知度が高まったこと や，申し込みや投稿をWeb 上で行うことができるよ うになり，学校内の様々な理科系クラブからの投稿 が容易になったことをあげている。

\section{2 発表分野ごとの傾向}

図 3 より，第 20 回（1981 年度）までは生物, 地 学分野が多数を占めており（第 20 回までの発表件数 合計 306 件中の 242 件， $79 \%$ )，それ以降，物理・化 学の発表が増加していることがわかる。

物理分野では，うちわ，紙飛行機など，自宅で 調査しやすいテーマから，ペットボトルロケット， シャープペンシルの芯の発光実験など, グループで 楽しんで実験できる研究テーマが多くみられた。ま た，生物分野では学校周辺の植物の分布，マウスゃ ショウジョウバエなどを使った研究といったテーマ の人気が高い一方, 継続的な観察を要する飼育記録 はあまりみられなかった。地学分野では, 部活動の 巡検で訪問した地域の地層や化石についての報告や， 
天体観測の結果報告が中心であった。近年は, アマ チュア無線, 太陽の黑点観察など, 部活動として長 期的に取り組んでいるテーマの継続報告も印象に 残った。

\section{3 研究報告中の図版等の活用状況の推移}

次に, 生徒がどのように研究内容を表現している か，また，どのように実験デー夕を処理している かを調査するため, 過去 15 年間の研究報告を分析 した。

研究報告の分量は, 第 41〜 49 回はB5 サイズで 2 ページ, 50 回以降は B5 サイズの 2 ページを A4 サイ ズで 1 ページに圧縮したものであり, 分量に差はな いと考えてよい。

研究報告中のグラフ, 表, 図・イラスト, 写真の 使用状況を調へ， その年度の発表総数に占める割合 を表したものが図 4 である。なお，ひとつの研究報 告中にグラフが複数ある場合も 1 件と数えた（表,
図・イラスト，写真についても同様）。したがって， 年度ごとの割合の和は $100 \%$ にならない。

図 4 より,ここ 10 年間のうちに, 図やイラスト を用いた表現を含む研究報告の割合が減少し，写真 の占める割合が急増していることを見出すことがで きる。その理由として，デジタルカメラやタブレッ 卜端末の普及により, サンプルの写真を容易に撮影 できるようになったことがあげられる。以前は実験 装置の概要をスケッチや展開図で表現する場合が多 かったが，近年は実験装置の写真を掲載することが 中心になった。同様に, 動植物のスケッチも最近は ほとんど見られない。また, ここ 10 年間は, 研究報 の文書ファイルをアップロードする形式をとってい るため, 投稿形式の変化も原因の一つとして考えら れる。これらの背景をもとに, 化学分野の研究テー マの分析を行った。

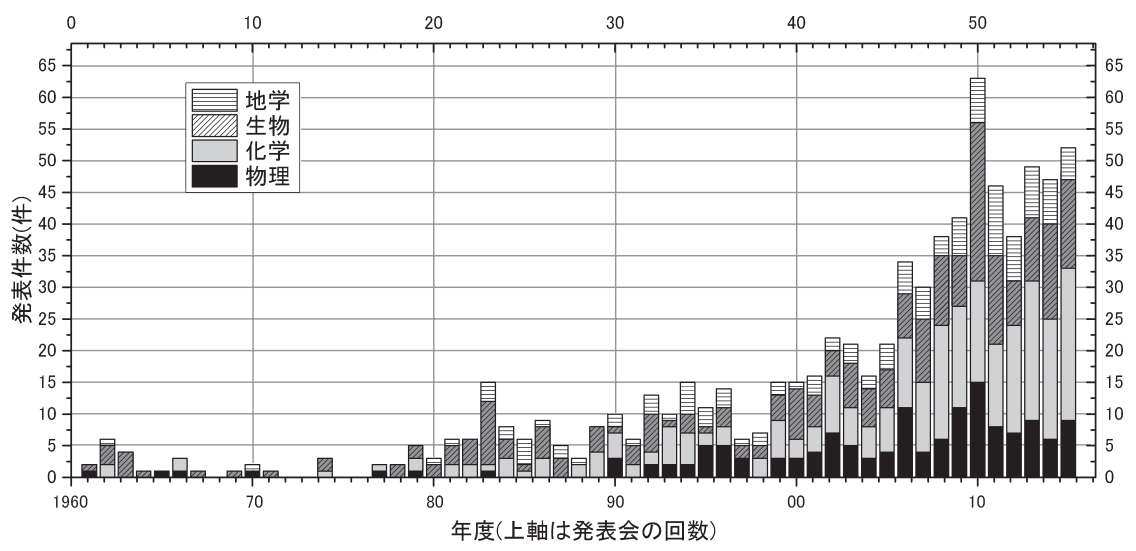

図 2 生徒理科研究発表会における,「中学校の部」の発表件数の推移

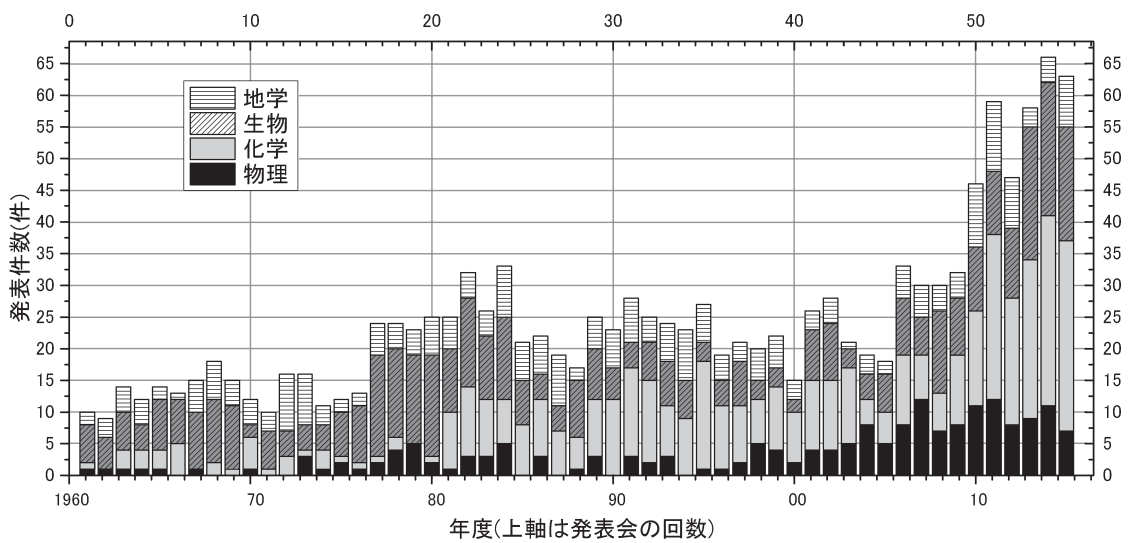

図 3 生徒理科研究発表会における,「高等学校の部」の発表件数の推移 


\section{4 化学分野における研究報告の分類}

化学分野で掲載された研究報告の分類を行った。 分類に際しては, 日本化学会の『実験で学ぶ化学の 世界』シリーズ（1996）に基づいて，12 の領域を設

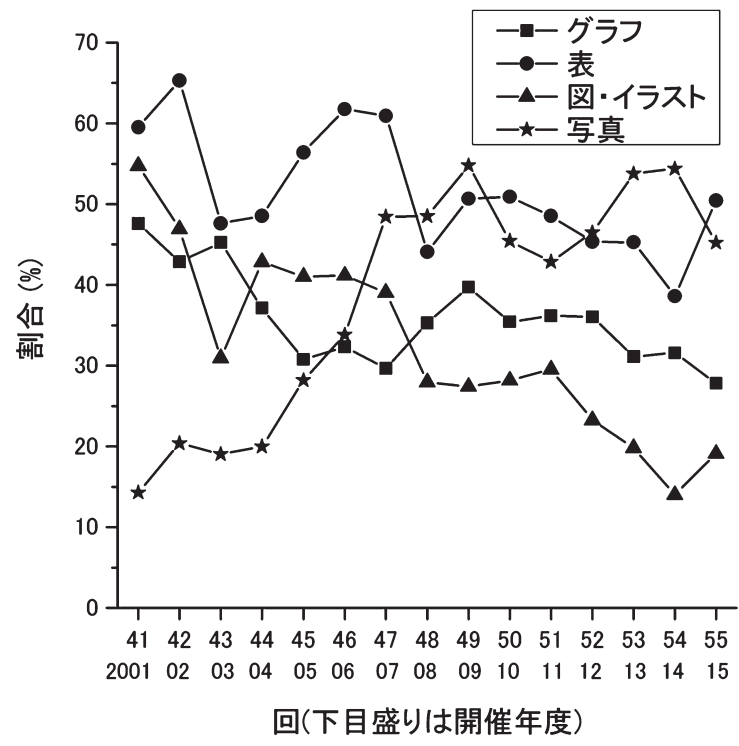

図 4 生徒理科研究発表会の研究報告における, 図版等 の活用状況の推移
定し，表 1 のように，内容を把握しやすい名称を与 えた。続いて，領域ごとに研究テーマを設定した。

理科 (化学) 系部活動の指導に際しては, これら の領域や研究テーマが現行の高等学校学習指導要領 にどう対応しているかを示すことは有益であると考 えられる。表 2 は, 高等学校学習指導要領（化学基 礎, 化学) に基づいて, 領域と研究テーマを分類 したものである。領域の後に示したカッコ付きの番 号は，研究テーマを表したものであり，後述する表 3 と対応している。なお, 同一の領域に属する研究 テーマであっても, 研究の対象や手法によっては, 学習指導要領上の異なる項目に位置づけられる場合 がある。

ここで設定した領域や研究テーマに基づき，研究 紀要に掲載された，中学校 260 件，高等学校 452 件

表 1 研究テーマ (化学分野) の分類

\begin{tabular}{|c|c|c|c|}
\hline & \multicolumn{3}{|c|}{ 領 域 名 } \\
\hline ア & 自然・環境 & キ & 化学の基礎 \\
\hline イ & 指示薬 ·色素 & ク & 食品の化学 \\
\hline ウ & 金属の性質 & ケ & 高分子化合物 \\
\hline I & ものづくり & コ & 有機化合物 \\
\hline オ & パターン現象 & サ & 電池 - 電解 \\
\hline 力 & 化学マジック & シ & 先端の化学 \\
\hline
\end{tabular}

表 2 高等学校学習指導要領（化学基礎, 化学）に基づく, 領域と研究テーマの分類

\begin{tabular}{|c|c|c|c|}
\hline 化学基礎 & & 化学 & \\
\hline 学習指導要領上の項目 & 領域とテーマ番号 & 学習指導要領上の項目 & 領域とテーマ番号 \\
\hline $\begin{array}{l}\text { (1) 化学と人間生活 } \\
\text { 化学と人間生活の関わり } \\
\text { 物質の探究 }\end{array}$ & $\begin{array}{ll}\text { ア } & \text { 自然・環境 (1) } \\
\text { イ } & \text { 指示薬・色素 }(2),(7) \\
\text { エ } & \text { もづくり (4), (19), (27) } \\
\text { カ } & \text { 化学マジック (33) } \\
\text { キ } & \text { 化学の基礎 } \\
& (10),(28),(38),(41)\end{array}$ & $\begin{array}{l}\text { (1) 物質の状態と平衡 } \\
\text { 物質の状態とその変化 } \\
\text { 溶液と平衡 }\end{array}$ & キ＼cjkstart化学の基礎（39） \\
\hline $\begin{array}{l}\text { (2) 物質の構成 } \\
\text { 物質の構成粒子 } \\
\text { 物質と化学結合 }\end{array}$ & & $\begin{array}{l}\text { (2) 物質の変化と平衡 } \\
\text { 化学反応とエネルギー } \\
\text { 化学反応と化学平衡 }\end{array}$ & $\begin{array}{ll}\text { エ } & \text { ものづくり }(22) \\
\text { オ } & \text { パターン現象 } \\
\text { カ } & \text { (5), (23) } \\
\text { カ } & \text { 化学マジック }{ }^{(6)}\end{array}$ \\
\hline $\begin{array}{l}\text { (3) 物質の変化 } \\
\text { 物質量と化学反応式 } \\
\text { 化学反応 } \\
\text { (酸・塩基, 酸化還元) }\end{array}$ & $\begin{array}{ll}\text { イ } & \text { 指示薬・色素 (2), (7) } \\
\text { ウ } & \text { 金属の性質 }(3) \\
\text { サ } & \text { 電池・電解 }(17),(24)\end{array}$ & $\begin{array}{l}\text { (3) 無機物質の性質と利用 } \\
\text { 無機物質 } \\
\text { 無機物質と人間生活 }\end{array}$ & $\begin{array}{ll}\text { ア } & \text { 自然・環境 }(8),(13) \\
\text { ウ } & \text { 金属の性質 } \\
& (11),(29),(30),(34),(35) \\
& \text { エ } \\
\text { ものづくり (9) }\end{array}$ \\
\hline & & $\begin{array}{l}\text { (4) 有機化合物の性質と利用 } \\
\text { 有機化合物 } \\
\text { 有機化合物と人間生活 }\end{array}$ & $\begin{array}{ll}\text { イ } & \text { 指示薬・色素 }(32) \\
コ & \text { 有機化合物 }(26),(37)\end{array}$ \\
\hline $\begin{array}{l}\lceil\text { 化学基礎」,「化学」の学 } \\
\text { 習指導要領上の項目に分 } \\
\text { 類されないもの }\end{array}$ & 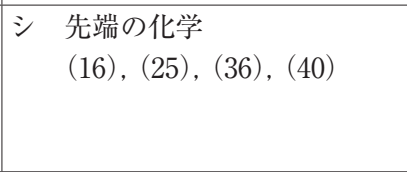 & $\begin{array}{l}\text { (5) 高分子化合物の性質と } \\
\text { 利用 } \\
\text { 高分子化合物 } \\
\text { 高分子化合物と人間生活 }\end{array}$ & $\begin{array}{ll}\text { カ } & \text { 化学マジック (18) } \\
\text { ク } & \text { 食品の化学 } \\
& (12),(15),(21) \\
\text { ヶ } & \text { 高分子化合物 (14), (31) }\end{array}$ \\
\hline
\end{tabular}


表 3 生徒理科研究発表会（化学分野）における研究報告の分類と発表件数の推移

\begin{tabular}{|c|c|c|c|c|c|c|c|c|}
\hline & & & 校分野 ( & 句数と西| & & & & \\
\hline 領域 & 研究テーマ & $\begin{array}{l}\text { 第1 } \\
30 \text { 回 }\end{array}$ & $\begin{array}{c}\text { 第 31 } \\
40 \text { 回 }\end{array}$ & $\begin{array}{c}\text { 第 41 } \\
50 \text { 回 }\end{array}$ & $\begin{array}{c}\text { 第 51 } \\
55 \text { 回 }\end{array}$ & $\begin{array}{l}\text { 高 } \\
\text { 校 }\end{array}$ & $\begin{array}{l}\text { 中 } \\
\text { 学 }\end{array}$ & 総 \\
\hline & & $\begin{array}{c}1961 \sim \\
1990\end{array}$ & $\begin{array}{c}1991 \sim \\
2000\end{array}$ & $\begin{array}{c}2001 \sim \\
2010\end{array}$ & $\begin{array}{c}2011 \sim \\
2015\end{array}$ & 吱 & 喜 & \\
\hline 自然・環境 & （1）水質調査 & 20 & 13 & 10 & 3 & 46 & 7 & 53 \\
\hline 指示薬・色素 & (2) 色素の性質・瀻維の染色 & 7 & 3 & 5 & 9 & 24 & 15 & 39 \\
\hline ウ＼cjkstart金属の性質 & （3）金属樹，銀鏡作り & 4 & 5 & 4 & 6 & 19 & 18 & 37 \\
\hline エ ものづくり & （4） セッケン, ロウソク作り & 1 & 20 & 3 & 2 & 26 & 6 & 32 \\
\hline 才 パターン現象 & （5）時計反応，振動反応（BZ，BR） & 0 & 5 & 5 & 6 & 16 & 15 & 31 \\
\hline カ 化学マジック & （6）ルミノール反応・化学発光 & 4 & 4 & 2 & 7 & 17 & 12 & 29 \\
\hline 1 指示薬・色素 & （7）植物・食品からの色素の抽出 & 8 & 3 & 2 & 8 & 21 & 8 & 29 \\
\hline ア 自然·環境 & (8) 酸性雨, 大気の窒素酸化物の定量 & 8 & 6 & 2 & 0 & 16 & 5 & 21 \\
\hline エ ものづくり & (9) 色ガラスの合成 & 4 & 2 & 5 & 6 & 17 & 4 & 21 \\
\hline キ 化学の基礎 & （10）再結晶, 尿素の花 & 3 & 0 & 0 & 1 & 4 & 16 & 20 \\
\hline ウ 金属の性質 & （11）合金作り & 5 & 1 & 2 & 2 & 10 & 10 & 20 \\
\hline ク 食品の化学 & （12）タンパク質の分解・変性 & 3 & 4 & 3 & 6 & 16 & 3 & 19 \\
\hline ア 自然・環境 & （13）多孔性材料による水の浄化 & 4 & 2 & 3 & 4 & 13 & 5 & 18 \\
\hline ケ 高分子化合物 & （14）樹脂の合成（ナイロン, ポリスチレン） & 2 & 2 & 3 & 3 & 10 & 8 & 18 \\
\hline ク 食品の化学 & （15）豆腐, ヨーグルト, 綿菓子, プリン等 & 5 & 1 & 2 & 3 & 11 & 6 & 17 \\
\hline シ 先端の化学 & （16）光触媒による化合物の分解 & 0 & 6 & 3 & 3 & 12 & 4 & 16 \\
\hline サ＼cjkstart電池・電解 & （17）電池（ダニエル, 備長炭, 果物電池) & 0 & 0 & 2 & 4 & 6 & 10 & 16 \\
\hline 力 化学マジック & (18) スライム, 人工イクラ & 0 & 0 & 2 & 5 & 7 & 8 & 15 \\
\hline エ ものづくり & (19）植物繊維・牛乳パックからの紙作り & 2 & 6 & 2 & 0 & 10 & 5 & 15 \\
\hline 亿 指示薬・色素 & （20）指示薬の性質（紅茶の色変化含む） & 4 & 2 & 3 & 2 & 11 & 4 & 15 \\
\hline ク 食品の化学 & （21）食品中の塩分の定量 & 5 & 2 & 0 & 3 & 10 & 4 & 14 \\
\hline エ ものづくり & (22) 化学カイロ作り & 3 & 0 & 2 & 0 & 5 & 8 & 13 \\
\hline 才 パターン現象 & (23) リーゼガング現象, ゲル中の金属樹 & 2 & 0 & 3 & 2 & 7 & 5 & 12 \\
\hline サ＼cjkstart電池・電解 & （24）電気分解による極板・溶液の変化 & 1 & 0 & 0 & 5 & 6 & 6 & 12 \\
\hline シ 先端の化学 & （25）超伝導体・磁性体の焼成 & 8 & 1 & 2 & 0 & 11 & 0 & 11 \\
\hline コ 有機化合物 & （26）エステルの合成, 香料 & 3 & 1 & 0 & 3 & 7 & 4 & 11 \\
\hline エ ものづくり & (27) チョーク作り & 1 & 0 & 2 & 1 & 4 & 6 & 10 \\
\hline キ 化学の基礎 & （28）反応速度, 気体の発生 & 0 & 0 & 4 & 2 & 6 & 4 & 10 \\
\hline ウ 金属の性質 & （29）鉄の酸化（サビ） & 4 & 1 & 0 & 0 & 5 & 5 & 10 \\
\hline ウ＼cjkstart金属の性質 & （30）錯体の合成 & 1 & 0 & 3 & 2 & 6 & 4 & 10 \\
\hline ケ 高分子化合物 & （31）吸水性高分子, イオン交換樹脂 & 2 & 3 & 0 & 1 & 6 & 4 & 10 \\
\hline 亿 指示薬・色素 & （32）洗濯の効果, 繊維の脱色, 界面活性剂 & 3 & 3 & 0 & 0 & 6 & 4 & 10 \\
\hline カ 化学マジック & (33) シャボン玉 & 1 & 0 & 1 & 1 & 3 & 6 & 9 \\
\hline ウ＼cjkstart金属の性質 & （34）青写真, 銀塩写真 & 0 & 0 & 3 & 4 & 7 & 2 & 9 \\
\hline ウ 金属の性質 & （35）テルミット, たたら製鉄 & 0 & 0 & 2 & 1 & 3 & 5 & 8 \\
\hline シ 先端の化学 & （36）色素増感太陽電池 & 0 & 0 & 4 & 1 & 5 & 3 & 8 \\
\hline コ 有機化合物 & （37）有機化合物の合成（アゾ染料等） & 1 & 1 & 1 & 3 & 6 & 2 & 8 \\
\hline キ 化学の基礎 & （38）水溶液の凝固, 蒸留 & 0 & 2 & 1 & 0 & 3 & 4 & 7 \\
\hline キ 化学の基礎 & （39）状態変化（ドライアイス, 気球等） & 1 & 2 & 0 & 0 & 3 & 4 & 7 \\
\hline シ 先端の化学 & (40) 無機蛍光体の合成 & 0 & 0 & 1 & 2 & 3 & 4 & 7 \\
\hline キ 化学の基礎 & (41) ペーパークロマトグラフィー, 万過 & 0 & 0 & 0 & 0 & 0 & 5 & 5 \\
\hline
\end{tabular}

網掛けは中学・高校それぞれの人気べスト 5 を表す。 
表 4 生徒理科研究発表会（化学分野）における, 領域ごとの発表件数の推移

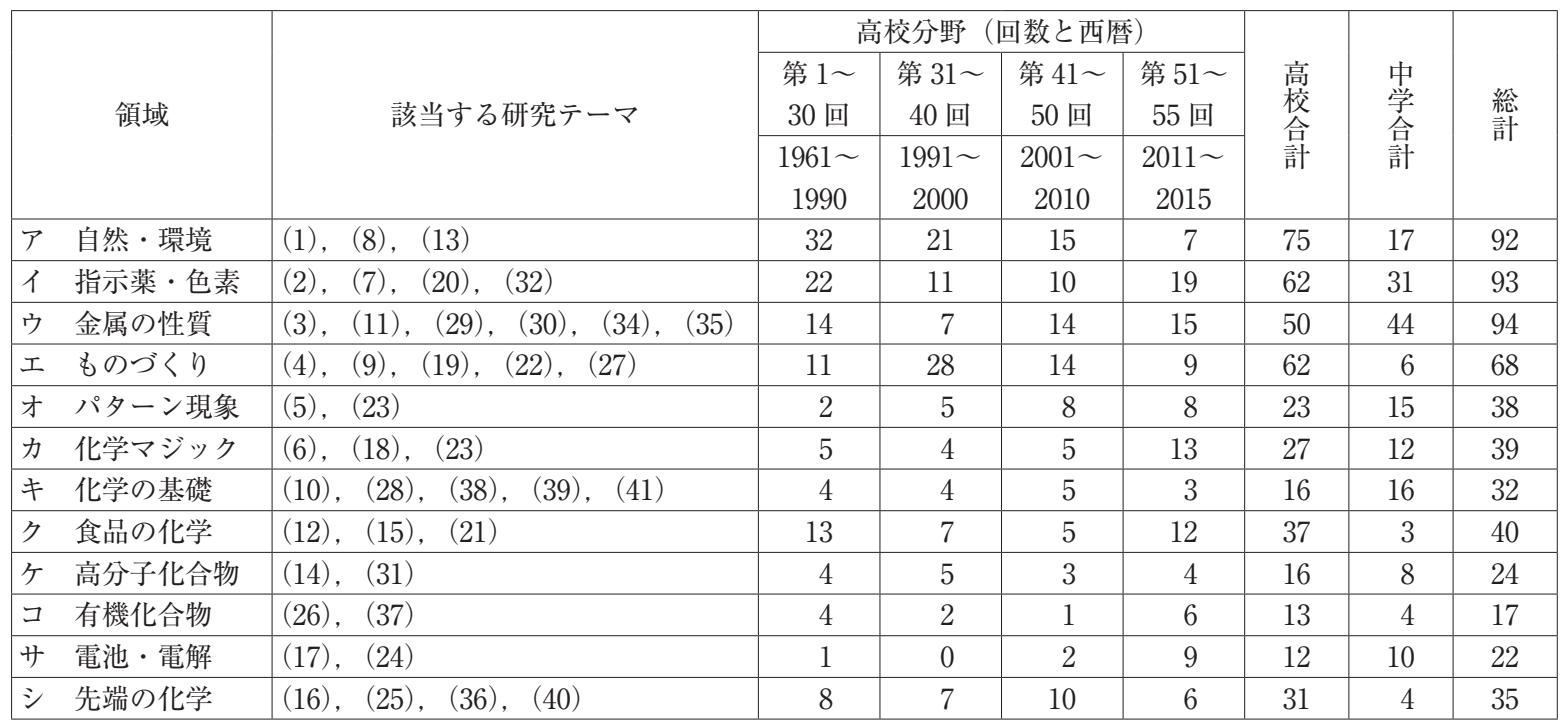

の研究報告を分類したものが表 3 である（発表件数 が 5 回以上のもののみ掲載した)。また, 領域ごとに 発表件数を集計したものが表 4 である。

領域ごとに研究内容の特徵, 時代ごとの傾向を述 ベる。

\section{ア【自然・環境】}

「(1) 水質調査」は歴史ある研究テーマである。研 究発表会の草創期は, 各イオンの定量はEDTA 法, Mohr 法などの定量実験によって決定しており，検水 をいったん学校に持ち帰って測定していたようであ る。パックテスト（(株）共立理化学研究所製）が市 販されるのが 1973 年であり, それ以降, 実施する学 校が増加していった。

また，パックテストの普及により，「(8) 酸性雨, 大気の窒素酸化物の定量」,「(13) 多孔性材料による 水の浄化」のような, 経時変化に注目する研究も増 加していった。これは, 1970 年代の高等学校化学教 科書において,「硫黄酸化物や窒素酸化物が大気污染 や酸性雨などの環境破壊を引き起こすことの記述が 顕著になっている」(郡司, 2014）ことの影響も大き いと考えられる

近年は, 動植物の生態や地質的な要因と関連させ て, 生物・地学分野で発表する場合が多く, 水質調 査を主目的とする化学の探究活動は減少傾向にある。

\section{イ【指示薬・色素】}

中学・高校ともに「(2) 色素の性質・繊維の染
色」,「(7) 植物・食品からの色素の抽出」の人気が あり，草木染め，多瀻交織布を利用した染まり方の 違いのほか, 「(32) 洗濯の効果, 繊維の脱色, 界面 活性剂」とも関連する, 染色後の色素の定着に注目 した研究も多い。また,「(20) 指示薬の性質（紅茶 の色変化含む)」のように, 家庭で入手できる酸・塩 基と紅茶の色素との反応による色変化も草創期から 行われている。

\section{ウ【金属の性質】}

金属のイオン化傾向の違いを利用した「(3) 金属 樹, 銀鏡作り」が多い。なかでも, 金属樹は中学校で 扱う試薬でも観察できることから，短期間で結果を 得やすいテーマとして適していると考えられる。近 年では，乃紙上で成長させた金属樹をラミネートし て保存する研究報告も知られており（土屋，2011）, イベントで製作体験を行っている学校もある。

また,「(11）合金作り」では黄銅の作成が中学・ 高校ともに実践されているほか, 「(29) 鉄の酸化 (サビ)」では，エバンスの実験に代表される酸化メ カニズムの追試が多い。この実験の概要および教材 化に向けての条件検討については小野寺ら（2012） による報告がある。このほか，コバルトのアンミン 錯体や遷移金属の錯イオンに注目した「（30）錯体の 合成」や, 「(34) 青写真, 銀塩写真」に数年間取り 組む生徒もいる。なお，激しい化学反応で知られる 「（35）テルミット，たたら製鉄」の実験を名物とす る学校もある。 


\section{エ【ものづくり】}

「（4）セッケン，ロウソク作り」，「(19) 植物繊 維・牛乳パックからの紙作り」,「(22) 化学カイロ作 り」は生活に根差しており, 本発表会に限らず, 幅 広く実践されている。「(27) チョーク作り」は, 廃 チョークを回収して再生するというものである。

「(9）色ガラスの合成」とは, 酸化鉛（II）とホウ 砂などを使ったガラスを指し, 金属塩の添加による 色の違いに注目する研究が多い。

\section{オ【パターン現象】}

$\lceil(5)$ 時計反応, 振動反応 $(\mathrm{BZ}, \mathrm{BR})\rfloor$ は, 混合水 溶液の色が一定時間後に黒変したり, もしくは, 周 期的な色変化を繰り返す化学反応である。中学・高 等学校の部活動や文化祭などのデモンストレーショ ンでよく実践される。また,「(23) リーゼガング 現象, ゲル中の金属樹」は, ゲル内部に生成する パターンが美しい実験である。人羅・松岡・柳澤 （2013）は，溶液の濃度を変えることでパターンが変 化するため, 探究活動の題材として人気があること を指摘している。

これらの実験は専門家の間では古くから知られて いたが, 探究活動の題材として実践されるように なったのは, 日本化学会から刊行された実験書『教 師と学生のための化学実験』(1987), および, 『教師 のためのケミカルデモンストレーション』シリーズ （1998）に掲載された影響が大きいと考えられる。

\section{カ【化学マジック】}

「(6) ルミノール反応・化学発光」は文化祭などで 人気の暗室実験であるほか, 触媒の違いによる発光 強度の変化, フルオレセインやローダミン B な゙の 蛍光色素を加えた際の発光の変化などの研究がみら れる。「(18) スライム, 人工イクラ」は定番の体験 実験であるほか, 「(33) シャボン玉」では, 家庭で できる実験や，巨大な（人が入れる）シャボン玉作 りに必要なシャボン液の調製についての報告がある。

\section{キ【化学の基礎】}

この領域は中学生の報告が多い。ミョウバンの大 きな結晶づくりを含む「(10) 再結晶, 尿素の花」の ほか, 状態変化に注目する「(38) 水溶液の凝固, 蒸 留」,「(39) 状態変化 (ドライアイス, 気球等)」も 実施しやすいテーマである。「(41) ペーパークロマ トグラフィー, ろ過」では, サインペンの色素の分 離や, 活性炭による色素水溶液の脱色など, 「市販品 を用いた，典型的な分離操作を体験できる実験（松
岡, 2012)」が多くみられた。また,「(28) 反応速 度, 気体の発生」では, 石灰石と塩酸の反応におけ る量的関係の検証，酸化マンガン (IV) による過酸 化水素水の分解の反応速度の測定などが確認された。

\section{ク【食品の化学】}

「(15）豆腐，ヨーグルト，綿菓子，プリン等」の 食品を作る実験は，女子中学・高校生を中心に人気 のテーマである。「(12) タンパク質の分解・変性」 では，ジャガイモなどを使ったカタラーゼによる 過酸化水素水の分解, タンパク質の検出反応, パイ ナップルがゼリーを分解する実験などが多くみられ た。また，「(21）食品中の塩分の定量」などにチャ レンジした高校生も多い。

\section{ケ【高分子化合物】, コ【有機化合物】}

香りや色を楽しむことのできる「(26) エステルの 合成, 香料」「(37) 有機化合物の合成（アゾ染料, フェノールフタレイン等)」のほか, 6,6-ナイロン の界面重合を含む「(14) 樹脂の合成（ナイロン，ポ リスチレン)」が多くみられ，数年間かけて取り組ん だ生徒が多いのが有機化合物の領域の特徵である。 このほか,「(31) 吸水性高分子, イオン交換樹脂」 のような, 市販の素材を用いて比較実験を行った研 究報告もある。

\section{サ【電池・電解】}

「(17) 電池（ダニエル，備長炭，果物電池）」は中 学校の授業でも扱う内容であり, 果物電池では, 果 物や極板の種類を変えた場合の起電力の変化に着目 した研究報告が中心である。高校生では, 重力電池, 覀酸化銅光電池などの報告がみられた。また，「(24) 電気分解による極板・溶液の変化」は中・高校とも ひろく行われている。

\section{シ【先端の化学】}

「(16）光触媒による化合物の分解」は, 二酸化于 タンによる色素や有機化合物の分解に焦点を当てた ものである。近年, 「(36) 色素増感太陽電池」の研 究も毎年 1,2 件みられる。このような先端の実験 を中等教育の現場で実践できるようにアレンジした, 日本化学会の『実験で学ぶ化学の世界』シリーズ （1996）の刊行は, 探究活動のテーマの多様化を後押 ししたと考えられる。上記実験書にも掲載されてい る「(25) 超伝導体・磁性体の焼成」,「(40) 無機蛍 光体の合成」は, 理工系大学の附属校で実践されて いる。 
表 5 日本学生科学賞中央審査に東京都から出品された 作品 (高校化学分野)

\begin{tabular}{ll}
\hline 年度 & \multicolumn{1}{c}{ 作品名 } \\
\hline 2010 & ○ヨウ化鉛 (II) 系リーゼガング現象 \\
& ○多孔質ガラスの研究 \\
2011 & ○人エクラとマイクロカプセル \\
& 触媒添加によるポリ乳酸の違い \\
2012 & アセチルサリチル酸合成法の検討 \\
& 金樹の夢の研究 \\
2013 & ○混合リーゼガング現象の研究 \\
2014 & ○ケカルガーデンの研究 \\
& ○二層系BR反応の研究 \\
2015 & 平面的に成長する銀樹の研究III \\
& 天然物を用いた色素增感太陽電池 \\
& ○試薬管理システムの研究と開発 \\
\hline
\end{tabular}

\section{5 論文コンクールとの接続}

全国的な論文コンクールである日本学生科学賞 (読売新聞社主催) では，9１0月に行われる都道府 県審査で評価された作品が $11 ， 12$ 月の中央審査に 推薦される。なお, 全国審査で入選・入賞した作品 の研究要旨は打茶の水女子大学サイエンス \&エデュ ケーションセンターの「理科自由研究データベース」 で公開されている。上記データベースを運営してい る千葉・植竹・垣内（2014）は, 「指導者が適切にア ドバイスを行う際に自由研究・課題研究を検索でき るシステムが大いに役立つと考えられる。（中略）当 初，こちらが想定していなかった活用法として，コ ンクール応募作品の審査をするときに, 審査員が チェックするために適しているという指摘があった。 逆に考えれば，理科自由研究データベースによって， 先行作品内容の剽窃・盗作が行い難くなったことを 示している。」，その有用性を評価している。

表 5 は, 日本学生科学賞中央審査に東京都から出 品された作品（高校化学分野）を挙げたものである。 表中に○印を付けた作品は, 生徒理科研究発表会で 中間報告が発表されたものである。

生徒理科研究発表会の当日 (2016 年 2 月), 運営 委員会の先生方と意見交換を行った。この研究発表 会は，時として競争原理が働く論文コンクールへの 応募を目標としたものではないため, 生徒が気軽に 参加できる点が広く受け入れられているということ である。自分達とは異なるテーマで探究活動に取り 組む他校の生徒達の熱意から学ぶことも多く, 研究 継続の動機づけとしても得がたい機会となっている という指摘もあった。また，この発表会での中間報 告を踏まえ, あと半年間で研究を仕上げ，秋の論文
コンクールにチャレンジする生徒も多いということ で，様々な生徒にチャンスを与えるこの発表会の魅 力を感じることができた。

\section{5. まとめ}

中学・高等学校の理科系部活動では, 継続的な探 究活動が実践されている。本研究では，東京都の私 立中学・高等学校の理科系部活動に注目し, テーマ 選択や，研究報告の形式について調査を行った。続 いて，学校周辺の自然環境の影響を受けにくい化学 分野を中心に，探究活動のテーマについて，学校種 や時代背景を踏まえつつ分析した。

その結果，生物・地学分野は安定した人気がある が, 近年, 物理・化学分野の研究報告が増えている ことが確認された。さらに，研究報告からスケッチ が失われつつあり，かわりに，写真で表現する割合 が急増していることを見出した。

理科系部活動ではテーマ設定や変更が容易であり, 生徒達が関心を持った研究テーマを設定しやすい利 点がある。本調查の結果, 理科 (化学) 系部活動で は教科書や実験書に根差した研究テーマを選択する 傾向がみられ，これは，小・中学生の自由研究を調 査した日比野ら（2014）の分析と対応する。そのた め，指導者もアドバイスを与えやすいことが，生徒 の目的意識の向上につながり, 継続的な探究活動の 実施に結び付いたと推測される。

近年, 国立研究開発法人科学技術振興機構 (JST) で実施されている「中高生の科学研究実践活動推進 プログラム」では, 学校と大学等が連携し, 生徒自 らが進める探究活動の取り組みを支援している。理 科の学習に意欲ある生徒に発展的な学習環境を提供 するためには，このような事業の活用を含め，校内 で探究活動へ取り組む環境を充実させていくことが 重要であると考える。

\section{謝辞}

東京私立中学高等学校協会文化部・生徒理科研究 発表会運営委員会の方々には，調查に協力いただき ました。心より感謝申し上げます。

また，本研究は（財）中谷電子計測技術振興財団 の支援を得て実施された。

\section{註}

1）自由研究という用語は古くは大正期から使われてお り, 安藤（2007a）は自由研究の誕生とその経緯，文 献による自由研究の定義の違いについて調査を行って いる。 
ところで, 現行の小学校・ 中学校の学習指導要領には 自由研究に関する記載はない。一方, 高等学校の学習 指導要領 (2009) では, 理科の各科目で「探究活動」 (学習活動と関連させながら観察, 実験を行い, 報告 書を作成させたり発表を行う機会を設けたりするこ と）が期待されている。また,「理科課題研究」とい う科目では, 「個人又はグループで研究を行わせ, 科学 的に探究する能力と態度を育てるとともに, 創造的な 思考力を養う」ことを意眓しており, 履修により単位 が与えられる。このほか, 理数・工業・農業・水産の 専門学科でも「課題研究」の科目が設定されている。 このような用語の使い分けを踏まえ, 本論文では, 夏 休みなどを利用して, 必要に応じて保護者や指導者の 支援を受けながら行う取り組みを「自由研究」, 部活 動で行われる継続的な研究活動を「探究活動」, スー パーサイエンスハイスクール (SSH) や専門学科など で行われる, 授業に組み込まれた研究活動を「課題研 究」とした。

\section{引用文献}

安藤秀俊 (2007a)「理科における自由研究の再考一川崎市 における取り組みを例とした科学コンテストとしての 今日的な意義と役割一」『理科教育学研究』第 48 巻, 第 1号, 1-11.

安藤秀俊 (2007b)「理科の自由研究における教師の認識に 関する一考察」『理科教育学研究』第 48 巻, 第 2 号, $127-134$.

千葉和義 - 植竹紀子 - 垣内康孝 (2014)「児童生徒の探究活 動支援のための理科自由研究データベース」『理科の 教育』第 64 巻, 第 11 号, 677-680.

(独) 科学技術振興機構理数学習支援センター編 (2013) 「平成 24 年度 中学校理科教育実態調査集計結果（速 報) 」, 114 .

(独) 科学技術振興機構理数教育支援センター編 (2009) 「平成 20 年度小学校理科教育実態調査及び中学校理科 教師実態調査に関する報告書」, 75 .

（独）国立青少年教育振興機構青少年教育研究センター編 （2014）「高校生の科学等に関する意識調査報告書一日 本·米国・中国・韓国の比較一」, 33-37.

郡司賀透 (2014)「戦後発行の高等学校化学教科書における 二酸化硫黄に関する記述内容の移り変わり一化学工業 および環境問題との関わりに焦点を当てて一」『理科 教育学研究』第 55 巻, 第 3 号, 299-310.

日比野佑希 - 森温子 - 青木祐佳 - 三宅崇 (2014)「岐阜市に おける小中学生の理科自由研究テーマの変化と傾向」 『岐阜大学教育学部研究紀要 (自然科学)』第 38 巻, 49-53.

人羅智恵・松岡雅忠・柳澤秀樹 (2013)「リーゼガング現象
の探究」『化学と教育』第 61 巻, 第 7 号, 352-353.

木村幸泰 (2014)「科学部の探究活動の意義や価值一理科研 究と科学コンクールー」『理科の教育』第 64 巻, 第 11 号, 685-688.

松岡雅忠 (2012)「ペーパークロマトグラフィーを中心と した色素の実験」『化学と教育』第 60 巻, 第 12 号, 516-517.

文部科学省（2009）『高等学校学習指導要領解説理科編』大 日本図書

文部科学省（2009）『高等学校学習指導要領解説理数編』大 日本図書

文部科学省（2016）「スーパーサイエンスハイスクール (SSH) 支援事業」Retrieved from http://www.mext.go.jp/b_menu/ houdou/28/08/_icsFiles/afieldfile/2016/08/15/1375845_02. pdf (2016.9.1 最終アクセス)

日本化学会編（1987）『教師と学生のための化学実験』東京 化学同人

日本化学会編（1996）『実験で学ぶ化学の世界 1-4』丸善

日本化学会編（1998）『教師のためのケミカルデモンスト レーション 1-7』丸善

お茶の水女子大学サイエンス\&エデュケーションセンター (2016)「理科自由研究データベース」Retrieved from http://sec-db.cf.ocha.ac.jp/ (2016.9.1 最終アクセス)

小野寺美佳 - 矢野慎 - 栃木優宏 - 長南幸安 (2012)「鉄さび の教材化の基礎研究 (第一報)」『弘前大学教育学部紀 要』第 108 号, 41-46.

大山光晴 (2015)「実験を工夫させる事前指導が自由研究 に与える効果」『理科教育学研究』第 56 巻, 第 2 号, 141-149.

新城和治 - 吉田一晴 - 山口喜七郎 - 屋良朝夫 - 長浜克重 （1977）「探究理科における自由研究の意義 II 自由研 究と授業との関連について一那覇市立小禄中学校にお ける「自由研究」実践事例の分析をとおして一」『琉 球大学教育学部紀要』第 21 集, 第 2 部, 7-27.

杉尾幸司 (2009)「那覇地区中学校における理科自由研究の 実態調査」『琉球大学教育学部教育実践総合センター 紀要』第 16 号, 95-101.

東京私立中学高等学校協会文化部編著（1976）『生徒理科研 究発表集録 (第 15 回)』東京私立中学高等学校協会

土屋徹（2012）「平面展開による金属樹の保存とイオン化 傾向の理解」『東レ理科教育賞受賞作品集』第 43 巻, 22-25.

海野桃子 - 安藤秀俊 (2009)「中学校における理科の自由研 究の現状一教科書での取扱いと中学生の意識一」『理 科教育学研究』第 50 巻, 第 2 号, 11-19.

(2016 年 5 月 31 日受付, 2016 年 12 月 28 日受理) 


\title{
A Study on Research Themes in Science Club Activities in Lower and Upper Secondary Schools
}

— Based on examples from research presentation workshops in Tokyo-

\author{
Masatada MATSUOKA ${ }^{1}$ \\ ${ }^{1}$ Komaba Toho Junior and Senior High School
}

\begin{abstract}
SUMMARY
For science club activities in lower and upper secondary schools, ongoing exploration activities with fixed themes are conducted. These are important opportunities to foster a love of science in students. One purpose of the present study was to investigate the reality of exploration activities conducted after school and over long school breaks. First, we targeted "student science research presentation workshops" with participating students from private lower and upper secondary schools in Tokyo. We organized and analyzed research reports from 759 lower secondary school students and 1,349 upper secondary schools students presented over 55 years between 1961 and 2015. The results of our analysis showed a recent increase in the number of applicants for physics and chemistry, a decrease in flora and fauna sketches in research reports and in the percentage of sketches on experimental devices, and a rapid increase in the percentage of photographs. Another purpose of this study was to investigate research themes centered on chemistry fields, which are thought to be less influenced by differences in school facilities and the natural environment around each school. We divided chemistry fields into 12 areas and analyzed overviews of each project and the popular points of each, taking into account school type and historical background. In chemistry fields, in addition to research that has traditionally been carried out regarding natural environments, we noted a tendency to select research themes focused on visual changes, such as changes in metal and chemical reactions involving dyeing and color changes.
\end{abstract}

$<$ Key words $>$ Research-based projects, experiments, chemistry, exploration activities 